\title{
Spatial Distribution of Serologically Reactive Sheep to Leptospira spp. in the Northeast Region of Brazil
}

\author{
José Dêvede da Silva $\oplus^{1}$, Maira Porto Viana $\oplus^{1}$, Lucas Gonzales Lima Pereira Calado ${ }^{2}$, \\ Ana Milena César Lima $\oplus^{3}$, Francisco Selmo Fernandes Alves ${ }^{4}$, Raymundo Rizaldo Pinheiro ${ }^{4}$, \\ Diego Figueiredo da Costa $\mathbb{D}^{5}$, Glaucenyra Cecília Pinheiro da Silva $\mathbb{D}^{6}$, \\ Sérgio Santos de Azevedo ${ }^{1}$ \& Clebert José Alves ${ }^{1}$
}

\begin{abstract}
Background: Considering the importance of leptospirosis in sheep farming and public health and the significance of identifying which serogroups circulate in sheep within each region, the objective of this study was to determine the seroprevalence and spatial distribution of the most frequent serogroups causing infection by Leptospira sp. in ovine herds in the Northeast region of Brazil.

Materials, Methods \& Results: Blood samples were collected from 4197 sheep from 229 herds in 7 Northeastern States. Sera were analyzed via microscopic agglutination test (MAT). The frequency of seroreactive sheep for Leptospira sp. was $14.06 \%$. The states of Alagoas, Ceará, Paraíba, Piauí, Rio Grande do Norte, and Sergipe, located in the Caatinga biome, had the highest frequencies of serologically reactive sheep, and Maranhão, in the Cerrado biome, had the lowest frequency. The most frequent serogroups were Autumnalis (19.49\%), Australis (15.76\%) and Serjoe (14.41\%). In the states of Ceará, Paraíba, Rio Grande do Norte, and Sergipe, $100 \%$ of their municipalities had at least one seroreactive animal. The highest frequencies of seropositive animals were found in the municipalities of União (50\%), Passagem (49.06\%), Canindé (48.89\%), Igaci (28.95\%), Gararu (31.2\%), Pirapemas (17.5\%), and Angicos (16\%) located in the states of Piauí, Paraíba, Ceará, Alagoas, Sergipe, Maranhão and Rio Grande do Norte, respectively.

Discussion: The animal-level prevalence (14.06\%) obtained in the present study is significant, especially considering the rustic nature of the species and the adverse conditions of the region for the infectious agent. In semi-arid conditions, it has been suggested that perhaps sheep do not seroconvert detectable titers on MAT with a cut-off point of 1:100. It is important to highlight that the ovine population in the Northeast region of Brazil is composed of mixed animals, which have been considered more resistant to infection by Leptospira spp. Also, environmental factors hostile to the survival of the infectious agent in the studied region should be taken into consideration, since they may have influenced the seropositive animal-level prevalence. A noteworthy variation was observed in agglutinin titers, which ranged from 100 to 1,600 , where $80.2 \%$ of the positive samples had titers $\leq 200$. It is important to highlight that more elevated titers $(\geq 400)$ were obtained in all seven states, which may suggest an acute infection caused by a non-adapted serovar, indicating that preventive and control measures focused on possible infection sources for sheep should be adopted. Although some states showed the same serogroups as the most frequent, a variety of serogroups was observed in municipalities, which may indicate different sources of infection, whether interspecies, intraspecies, or via alternative routes of transmission in semi-arid conditions, such as venereal. This indicates that even though sheep are more resistant to infection, they become exposed due to the environment or management conditions. As such, identification, isolation, and treatment of the affected animals are alternative measures recommended for prevention and control of leptospirosis in sheep in the semi-arid region. It is evident that despite the lack of rain observed in the last decade in the Northeast region of Brazil, which prevented the formation of favorable environments for the presence of Leptospira, the infectious agent remains among the sheep, as well as other production and wild animals in the region. Some factors may be contributing to this scenario, such as the fact that sheep farming in the region is characterized mainly by subsistence systems, where veterinary assistance and adequate sanitary management are absent, thus increasing the possibility of contact with Leptospira.
\end{abstract}

Keywords: small ruminants, semi-arid, zoonosis.

DOI: $10.22456 / 1679-9216.117519$

Accepted: 28 September 2021

Published: 9 November 2021 
J.D. Silva, M.P. Viana, L.G.L.P. Calado, et al. 2021. Spatial Distribution of Serologically Reactive Sheep to Leptospira spp. in

\section{INTRODUCTION}

The Brazilian sheep industry stands out in the national scenario for having great growth potential, with a significant increase in the herd [16].

Despite this increase, sanitary deficiencies involved in the evolution process of Brazilian sheep farming need to be resolved, such the economic losses caused by the loss of animals and the need to replace animals with infectious diseases [13]. Among these diseases, leptospirosis has a great economic impact on livestock and in public health, being an important disease in the sheep population and may manifest itself acutely with increased body temperature, anorexia, jaundice and anemic or hemorrhagic syndromes [1,11]. Frequently, in its chronic form, fertility is affected, and neonatal deaths, abortions and decreased milk production can occur, resulting in economic losses $[10,18]$. Even so, the disease is often ignored and its effects on sheep farming are usually underestimated, which is worrying in the Brazilian semi-arid region, where sheep farming is widely present $[15,16]$.

In the Northeast region of Brazil, there are no epidemiological studies for leptospirosis in sheep carried out based on planned sampling and that investigate several states and different biomes. Thus, considering the importance of the disease for public health and the role that sheep play in its epidemiology, the present objective was to determine the seroprevalence and spatial distribution of the most frequent serogroups responsible for infection by Leptospira sp. in sheep herds in the Northeast region of Brazil.

\section{MATERIALS AND METHODS}

Study area and sampling

The survey was conducted in Northeast region of Brazil, which is located in North-East position of country between $1^{\circ}$ and $18^{\circ} 30$ 'south latitude and $34^{\circ}$ $20^{\prime}$ ' and $48^{\circ} 30^{\prime}$ 'west longitude and covers $18.3 \%$ of territory with an area of $1,561,177.8 \mathrm{~km}^{2}$. It's composed of 1,793 municipalities, distributed in the states of Bahia, Ceará, Pernambuco, Paraíba, Rio Grande do Norte, Piauí, Maranhão, Alagoas and Sergipe, where more than 12 million sheep are concentrated, representing $66.7 \%$ of national sheep population $[16,31]$.

The survey was planned as part of the Zoosanitary Project, involving the partnership of EMBRAPA Goats and Sheep, and Ministry of Agriculture, Livestock and Supply of Brazil.
Young (6 to 12 months) and adult sheep were sampled from flocks located in microregions with significant population density of sheep in five states of Northeast region of Brazil: Alagoas, Ceará, Maranhão, Paraíba, Piauí, Rio Grande do Norte and Sergipe. Owners' membership was voluntary. The minimum number of flocks visited was calculated using the formula for simple random samples [32], considering the following parameters: prevalence of $28.20 \%$ of seropositive flocks [3], sampling error of $8 \%$ and confidence level of $95 \%$. According to these parameters the minimum sample number is 122 flocks, however, 190 were used.

The minimum number of animals to sampled in each herd was calculated with the formula for detecting the presence of disease [32], using following parameters: probability $(P)$ of $95 \%$ for detection of at least one seropositive animal in the herd and number of seropositive animals in the herd (d) assuming a herd prevalence of $13.45 \%$ [4]. In flocks with up to 20 animals, all sheep were sampled and 20 animals were selected when number of animals was greater than 20 .

Blood samples were collected from 4,197 sheep from 65 municipalities, distributed over 229 flocks (Figure 1). In the state of Alagoas, 413 samples were collected in 21 herds from 9 municipalities; in state of Ceará, 597 samples were collected in 33 flock from 10 municipalities; in the state of Maranhão, 346 samples were used in 18 herds from 8 municipalities; in state of Paraíba, 409 samples were collected in 23 flock from 8 municipalities; in state of Piauí, 747 samples from 42 flock belonging to 15 municipalities were used; in state of Rio Grande do Norte, 823 samples were collected from 45 flock in 7 municipalities; and in state of Sergipe, 862 samples from 47 flock in 8 municipalities were collected.

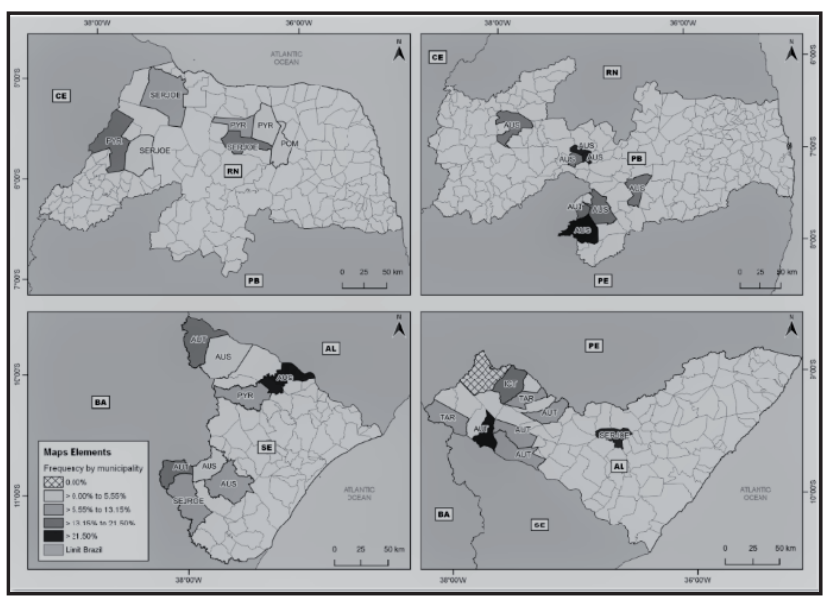

Figure 1. Leptospira sp. seroprevalence and most frequent serogroups in sheep per municipality in the states of Rio Grande do Norte, Paraíba, Sergipe and Alagoas, Northeast region of Brazil. 
J.D. Silva, M.P. Viana, L.G.L.P. Calado, et al. 2021. Spatial Distribution of Serologically Reactive Sheep to Leptospira spp. in

Field activities included blood collection and sending the samples to laboratory. Blood samples were collected from adult and young sheep, in $8 \mathrm{~mL}$ volumes, by puncture of the jugular vein with disposable needle and vacuum tube (without anticoagulant) with a capacity of $8.5 \mathrm{~mL}$. Serum samples were transferred to microtubes and frozen at $-20^{\circ} \mathrm{C}$ until the serological diagnosis was performed.

\section{Diagnostic Method}

The microscopic agglutination teste (MAT), standard method for serology of leptospirosis [25] was used. The antigens used were from Pasteur Institute $^{1}$ and provided by the Veterinary Bacteriology Laboratory ${ }^{2}$ of Fluminense Federal University, Niterói, Rio de Janeiro, Brazil. Serovars were as follows: Leptospira interrogans serovars Australis, Autumnalis, Bratislava, Batavie, Canicola, Copenhageni, Grippotyphosa, Hardjoprajitno, Hebdomadis, Icterohaemorrhagiae, Pomona, Pomona Fromm, Pyrogenes, Sentot and Wolffi; Leptospira borgpeterseni serovars Ballum, Castellonis, Hardjobovis, Javanica, Mini, Tarassovi and Whitcombi; Leptospira biflexa serovars Andamana and Patoc; Leptospira santarosai serovars Guaricura, Canalzoni and Shermani; Leptospira kirschneri serovars Butembo and Cynopteri; Leptospira noguchii serovars Lousiana and Panama; Leptospira weilli serovar Celledoni. Serum samples were screened at dilution of 1:100, and those that presented $50 \%$ or more agglutination were titrated by 2 -fold geometrical dilutions. The serum titer was a reciprocal of the highest dilution that presented positive result. The antigens were examined under the dark field microscope before the tests in order to verify the mobility and presence of self-agglutination or contaminants.

\section{Spatial distribution}

For the analysis of the spatial distribution of the frequency of Leptospira sp. and of the most frequent serogroups in the municipalities, the Google Earth Pro software and the construction of geographic maps using the QGIS 3.12.2 software $^{3}$ were used.

\section{Data analysis}

The comparison of the proportion of serorective animals among the states was performed with the Chi-squared test with 5\% significance level, by using the IBM ${ }^{\circledR}$ SPSS $^{\circledR}$ for Statistics $21^{4}$.

\section{RESULTS}

Of the 4,197 blood serum samples from the investigated sheep, 590 were seropositive (titer $\geq$ 100) for Leptospira spp., resulting in animal-level prevalence of $14.06 \%$ (IC 95\% $=0.1304-0.1514$ ). The states of Alagoas, Ceará, Paraíba, Piauí, Rio Grande do Norte, and Sergipe, located in the Caatinga biome, had the highest animal-level prevalence of seroreactive sheep, and Maranhão, in the Cerrado biome, had the lowest prevalence, with a statistical difference between the seven states $(P$ $<0.001$ ) [Table 1]. Titers varied from 100 to 1600 and the most frequent serogroups were Autumnalis (19.49\%), Australis (15.76\%), Serjoe (14.41\%), and Pyrogenes (13.22\%). Of the 590 positive samples, $473(80.2 \%)$ had titers between 100 and 200 (Table 2).

Of the 65 municipalities investigated, 62 $(95.4 \%)$ had at least one seropositive sheep. In the states of Ceará, Paraíba, Rio Grande do Norte, and Sergipe, $100 \%$ of their municipalities had at least one seroreactive animal. The others, Alagoas, Maranhão, and Piauí had $88.9 \%, 87.5 \%$, and $93.3 \%$ of their municipalities respectively test positive (Figures $1 \& 2$ ).

The highest animal-level prevalence of seropositive animals were observed in the municipalities of União (50\%), Passagem (49.06\%), Canindé (48.89\%), Igaci $(28.95 \%)$, Gararu (31.2\%), Pirapemas (17.5\%), and Angicos (16\%) located in the states of Piauí, Paraíba, Ceará, Alagoas, Sergipe, Maranhão and Rio Grande do Norte, respectively (Figures $1 \& 2$ ).

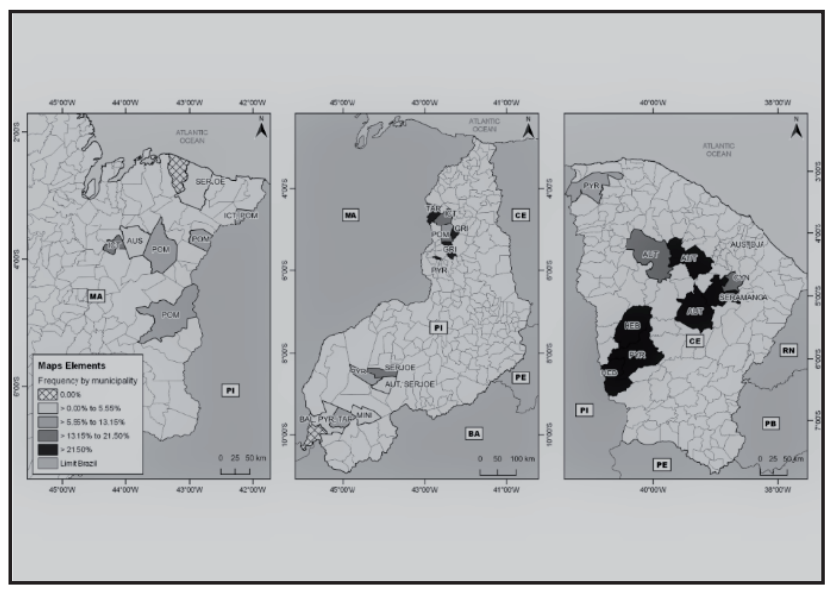

Figure 2. Leptospira sp. seroprevalence and most frequent serogroups in sheep per municipality in the states of Maranhão, Piauí, and Ceará, Northeast region of Brazil. 
J.D. Silva, M.P. Viana, L.G.L.P. Calado, et al. 2021. Spatial Distribution of Serologically Reactive Sheep to Leptospira spp. in the Northeast Region of Brazil.

Acta Scientiae Veterinariae. 49: 1837

Table 1. Seroprevalence for leptospirosis in sheep considering municipalities and animals in the States of Alagoas, Ceará, Maranhão, Paraíba, Piauí, Rio Grande do Norte, and Sergipe, and most frequently identified serogroup per state.

\begin{tabular}{|c|c|c|c|c|c|c|c|}
\hline \multirow[b]{2}{*}{ States } & \multicolumn{3}{|c|}{ Municipalities } & \multicolumn{3}{|c|}{ Animals } & \multirow{2}{*}{$\begin{array}{l}\text { Most frequent } \\
\text { serogroup }(\%)\end{array}$} \\
\hline & $\begin{array}{c}\text { Municipalities } \\
\text { N }\end{array}$ & $\begin{array}{l}\text { Positives } \\
\mathrm{N}(\%)\end{array}$ & IC $95 \%$ & $\underset{\mathrm{N}}{\text { Animals }}$ & $\begin{array}{l}\text { Positives } \\
\mathrm{N}(\%)\end{array}$ & CI $95 \%$ & \\
\hline Alagoas & 9 & $8(88.9)$ & $56.5-98.01$ & 413 & $52(12.6)$ & $9.7-16.1$ & Autumnalis (36.5) \\
\hline Ceará & 10 & $10(100)$ & $72.25-100$ & 597 & $142(23.8)$ & $20.5-27.3$ & Autumnalis (28.8) \\
\hline Maranhão & 8 & $7(87.5)$ & $52.9-97.76$ & 346 & $24(6.94)$ & $4.7-10.1$ & Pomona (41.7) \\
\hline Paraíba & 8 & $8(100)$ & $67.56-100$ & 409 & 109 (26.7) & $22.6-31.1$ & Australis (51.4) \\
\hline Piauí & 15 & $14(93.3)$ & $70.18-98.8$ & 747 & $83(11.11)$ & $9.0-13.5$ & Serjoe (21.7) \\
\hline Rio Grande do Norte & 7 & $7(100)$ & $64.57-100$ & 823 & $78(9.48)$ & $7.66-11.6$ & Serjoe (37.2) \\
\hline Sergipe & 8 & $8(100)$ & $67.56-100$ & 862 & $102(11.83)$ & $9.8-14.1$ & Autumnalis (29.4) \\
\hline Total & 65 & $62(95.4)$ & $87.28-98.4$ & 4.197 & $590(14.06)$ & $13.0-15.1$ & Autumnalis (19.5) \\
\hline
\end{tabular}

Table 2. Serogroups of Leptospira sp. most prevalent and respective titers, in sheep of the States of Alagoas, Ceará, Maranhão, Paraíba, Piauí, Rio Grande do Norte and Sergipe.

\begin{tabular}{|c|c|c|c|c|c|c|}
\hline \multirow{2}{*}{ Serogroups } & \multicolumn{5}{|c|}{ Titers } & \multirow{2}{*}{ Total $(\%)$} \\
\hline & 100 & 200 & 400 & 800 & 1,600 & \\
\hline Andamana & 1 & 0 & 0 & 0 & 0 & $1(0.17)$ \\
\hline Australis & 40 & 24 & 11 & 18 & 0 & $93(15.76)$ \\
\hline Autumnalis & 80 & 28 & 6 & 1 & 0 & 115 (19.49) \\
\hline Canicola & 4 & 2 & 0 & 0 & 0 & $6(1.02)$ \\
\hline Grippotyphosa & 3 & 4 & 4 & 3 & 0 & $14(2.37)$ \\
\hline Ballum & 10 & 4 & 0 & 0 & 0 & $14(2.37)$ \\
\hline Icterohaemorrhagiae & 33 & 8 & 11 & 2 & 0 & $54(9.15)$ \\
\hline Cynopteri & 3 & 8 & 1 & 0 & 0 & $12(2.03)$ \\
\hline Serjoe & 29 & 27 & 16 & 11 & 2 & $85(14.41)$ \\
\hline Hebdomadis & 7 & 8 & 2 & 8 & 0 & $25(4.24)$ \\
\hline Mini & 0 & 1 & 0 & 0 & 0 & $1(0.17)$ \\
\hline Panama & 1 & 0 & 0 & 0 & 0 & $1(0.17)$ \\
\hline Semaranga & 8 & 2 & 1 & 0 & 0 & $11(1.86)$ \\
\hline Pomona & 34 & 5 & 1 & 1 & 1 & $42(7.12)$ \\
\hline Pyrogenes & 46 & 21 & 10 & 1 & 0 & $78(13.22)$ \\
\hline Djasiman & 3 & 3 & 0 & 0 & 0 & $6(1.02)$ \\
\hline Shermani & 5 & 6 & 2 & 1 & 0 & $14(2.37)$ \\
\hline Tarassovi & 10 & 4 & 1 & 1 & 1 & $17(2.88)$ \\
\hline Celledoni & 1 & 0 & 0 & 0 & 0 & $1(0.17)$ \\
\hline Total $(\%)$ & $318(53.9)$ & $155(26.3)$ & $66(11.2)$ & $47(7.96)$ & $4(0.67)$ & $590(100)$ \\
\hline
\end{tabular}


J.D. Silva, M.P. Viana, L.G.L.P. Calado, et al. 2021. Spatial Distribution of Serologically Reactive Sheep to Leptospira spp. in

\section{DISCUSSION}

This is the first seroepidemiological investigation of leptospirosis in sheep using a planned sampling that is representative of the herds and animals in the Northeast region of Brazil obtained from 7 of the 8 states in that region. The majority of previous studies were localized serological surveys or had small isolated samplings per state [23,27].

The animal-level prevalence $(14.06 \%)$ obtained in the present study is significant, especially considering the rustic nature of the species and the adverse conditions of the region for the infectious agent. In semi-arid conditions, it has been suggested that perhaps sheep do not seroconvert detectable titers on MAT with a cut-off point of 1:100 [23,30]. It is important to highlight that the ovine population in the Northeast region of Brazil is composed of mixed animals, which have been considered more resistant to infection by Leptospira spp. [5,7]. Also, environmental factors hostile to the survival of the infectious agent in the studied region should be taken into consideration, since they may have influenced the seropositive animallevel prevalence.

In the distribution map for leptospirosis cases, higher animal-level prevalence was observed in the states of Alagoas, Ceará, Paraíba, Piauí, Rio Grande do Norte, and Sergipe, located within the Caatinga biome, while Maranhão, located in the Cerrado biome, had the lowest prevalence. Variation in the presence of seroreactive animals within the Caatinga biome when compared to the Cerrado biome, which has a mean annual rainfall of $1,500 \mathrm{~mm}$, supports the hypothesis that leptospirosis cannot be considered exclusive to areas with high precipitation and that in semi-arid conditions, the infectious agent may be transmitted via other routes of transmission, such as venereal in sheep [24,30].

A noteworthy variation was observed in agglutinin titers, which ranged from 100 to 1,600. Normally, antibody titers in sheep reach up to $200[23,27,29,30]$, which was also observed in the present study, where $80.2 \%$ of the positive samples had titers $\leq 200$. It is important to highlight that more elevated titers $(\geq 400)$ were obtained in all seven states, which may suggest an acute infection caused by a non-adapted serovar, indicating that preventive and control measures focused on possible infection sources for sheep should be adopted [1].
The predominant serogroups in this study were Autumnalis, Australis, Serjoe, and Pyrogenes, corresponding to $62.8 \%$ of positive reactions. When seropositive reactions were grouped per state, the Autumnalis serogroup predominated in Alagoas, Ceará, and Sergipe. This serogroup was also the most frequently observed in the Northeast in general, which may suggest the possibility of sheep being the reservoirs for this serogroup in the Caatinga biome, since it has been frequently reported in various studies performed in the Northeast region of Brazil [3,6,23], and was also isolated from sheep in the state of Rio Grande do Sul [28]. This implies that ovine have an important role in the epidemiology of leptospirosis, acting as a host for infection of other animals. It should be noted that in these states, a semi-intensive farming system is most common, sheep farming is more technified and geared toward pure-bred animals, which are more susceptible to infection [7].

In the states of Piauí and Rio Grande do Norte, the Serjoe serogroup was the most frequent. The presence of mixed herds with cattle in the studied properties should be taken into consideration since this type of management, under semi-arid conditions, favors the preservation and dissemination of Leptospira, as mentioned by [27]. The possibility of sheep harboring this serogroup should also be considered [20,26]. As such, it is possible to suggest that bovines are acting as a source of infection for sheeps, transmitting Leptospira via direct or indirect contact, since bovines are considered adapted hosts for this serogroup [19,20,27].

In the state of Paraíba, the highest animal-level prevalence was in the municipality of Passagem, located within the drought polygon, and which has semiarid climate and small properties dedicated to sheep and goat farming. Pombal had the lowest prevalence $(13.2 \%)$, closer to the prevalence observed for the Northeast region of Brazil (14.06\%); this is noteworthy because it was equivalent to the entire region. This high seropositivity was found in the entire state, which is concerning because this disease is responsible for impacting animal farming and is also of importance for public health [11].

The presence of the Pomona serogroup, the most frequent in the state of Maranhão, is considered accidental in sheep, indicating contact with swine populations, since the studied municipalities have a number of swine that reaches over 100,000 heads [16]. The 
swine population may have contaminated the environment, leading to infection of sheep. The municipality of Pirapemas, located in the North region of Maranhão, had the highest percentage of seropositive sheep, with the Icterohaemorrhagiae serogroup the most frequently observed, and elevated titers (400 to 800), which may suggest an acute infection, resulting in economic losses and a risk to public health, since carrier sheep eliminate bacteria in urine for a long period of time and may be a risk for zoonotic infection for people $[1,8]$. This serogroup has been associated with ovine infection in Brazil $[9,19,21]$. This may be attributed to environmental characteristics, presence of rodents and wild animals, as well as the presence of the Pirapemas river, a large affluent in the region which may influence the epidemiology of leptospirosis $[2,12,17]$.

The serogroup Australis, the most frequent serogroup observed in the state of Paraíba, was found in $87.5 \%$ of the investigated municipalities. It is worth noting that $13.2 \%$ was the lowest prevalence among the investigated municipalities in this state, and $28.4 \%$ of seroreactive animals had elevated titers (400 to 800), all located in areas of dry climate, reinforcing that the agent was present in hostile environments, and with possible contact with swine, equids, and rodents, since this serogroup is usually associated with these animals $[1,14,22]$. On geospatial analysis, the municipality of Monteiro stands out for its high animal-level prevalence and its border with the state of Pernambuco, which may be a risk due to interstate transit of animals. The same is true for the state of Ceará, where the municipality of Parambu had high seroreactivity and borders the state of Piauí, which had low seroreactivity levels. Therefore, implementation of oversight and control measures focused on animal transit should be improved.

The municipality of União, located in the Center-North Mesoregion of Piauí, had the highest percentage of seropositive sheep, with the Tarassovi serogroup the most frequent. When analyzing the spatial distribution for leptospirosis, it is possible to observe that the municipalities with the highest prevalence are located in the transition zone between the Cerrado and Caatinga biomes, with a diversity of ecosystems, several green areas and preserved areas, an extensive farming system with properties with over 100 acres, and also the presence of the Parnaíba river, which may justify the high frequency of seropositivity, since the presence and distribution of leptospirosis in ovine herds are directly related with environmental factors, such as precipitation, humidity, topography, and presence of rodents and wild animals [2].

Although some states showed the same serogroups as the most frequent, a variety of serogroups was observed in municipalities, which may indicate different sources of infection, whether interspecies, intraspecies, or via alternative routes of transmission in semi-arid conditions, such as venereal $[23,24,27]$. This indicates that even though sheep are more resistant to infection, they become exposed due to the environment or management conditions. As such, identification, isolation, and treatment of the affected animals are alternative measures recommended for prevention and control of leptospirosis in sheep in the semi-arid region.

It is evident that despite the lack of rain observed in the last decade in the Northeast region of Brazil, which prevented the formation of favorable environments for the presence of Leptospira, the infectious agent remains among the sheep, as well as other production and wild animals in the region. Some factors may be contributing to this scenario, such as the fact that sheep farming in the region is characterized mainly by subsistence systems, where veterinary assistance and adequate sanitary management are absent, thus increasing the possibility of contact with Leptospira.

\section{CONCLUSION}

The results of the present study show the distribution of Leptospira spp. infection in sheep in the Northeast region of Brazil. Intraspecies transmission seems to be the main route for dissemination of the disease in sheep, though other species of domestic and wild animals are important sources of infection. The animal-level prevalence points toward the necessity of implementing prevention and control measures, such as the use of adequate serology tests and reduction of the cut-off point to 1:50, and management practices that avoid dissemination of the infectious agent into the environment to break the transmission cycle for this disease.

\section{MANUFACTURERS}

${ }^{1}$ Institut Pasteur. Paris, France.

${ }^{2}$ Laboratory of Veterinary Bacteriology, Biomedical Institute, Fluminense Federal University (UFF). Niterói, RJ, Brazil.

${ }^{3}$ QGIS Development Team, Free and Open Software, Available on https://www.qgis.org/en/site/about/index.html.

${ }^{4}$ IBM@ - International Business Machines Corp. Armonk, NY, USA. 
J.D. Silva, M.P. Viana, L.G.L.P. Calado, et al. 2021. Spatial Distribution of Serologically Reactive Sheep to Leptospira spp. in

Funding. This research is financially supported by the Conselho Nacional de Desenvolvimento Científico e Tecnológico (CNPq)/ Ministério da Agricultura Pecuária e Abastecimento through Public Announcement 64/2008.

Acknowledgements. We thank the Coordination for the Improvement of Higher Level Personnel (CAPES) for granting us a Graduate Scholarship. We thank the Transmissible Diseases Research Group of the Federal University of Campina Grande (UFCG), Patos, PB for their commitment. Finally, we thank the
Animal Health Research Group of Embrapa Goat and Sheep, Sobral, CE for their cooperation.

Ethical approval. The project was approved by Research Ethics Committee (CEP), of the Rural Health and Technology Center - CSTR - UFCG, under protocol number 102/2017.

Declaration of interest. The authors report no conflicts of interest. The authors alone are responsible for the content and writing of paper.

\section{REFERENCES}

1 Adler B. \& Moctezuma A.P. 2010. Leptospira and leptospirosis. Veterinary Microbiology. 140(3-4): 287-296. doi: 10.1016 / j.vetmic.2009.03.012.

2 Alves C.J., Vasconcellos S.A., Camargo C.R.A \& Morais Z.M. 1996. Influência dos fatores ambientais sobre a proporção de caprinos soro-reatores para a leptospirose em cinco centros de criação do estado da Paraíba, Brasil. Arquivos Instituto Biológico. 63(2): 11-19.

3 Alves C.J., Alcindo J.F., Farias A.E.M., Higino S.S.S., Santos F.A., Azevedo S.S., Costa D.F. \& Santos C.S.A.B. 2012. Caracterização epidemiológica e fatores de risco associados à leptospirose em ovinos deslanados do semiárido Brasileiro. Pesquisa Veterinária Brasileira. 32(6): 523-528. doi.org/10.1590/S0100-736X2012000600009.

4 Alves J.R.A., Souza Lima G.M., Silva J.D., Costa D.F., Santos F.A., Higino S.S.S., Azevedo S.S. \& Alves C.J. 2017. Epidemiological characterization and risk factors associated with leptospirosis and brucellosis in small ruminants sold at animal fair in the Sertão Region of Pernambuco State, a semiarid Region of Northeastern Brazil. Semina: Ciências Agrárias. 38(4): 1933-1945. doi: 10.5433/1679-0359.2017v38n4p1933.

5 Cezar M.F., Souza B.B., Souza W.H., Pimenta Filho E.C., Tavares G.P. \& Medeiros G.X. 2004. Avaliação de parâmetros fisiológicos de ovinos Dorper, Santa Inês e seus mestiços perante condições climáticas do trópico semiárido nordestino. Ciência e Agrotecnologia. 28(3): 614-20. https://doi.org/10.1590/S1413-70542004000300018.

6 Costa D.F., Silva A.F., Brasil A.W.L., Loureiro A.P.P., Santos F.A., Azevedo S.S., Lilenbaum W. \& Alves C.J. 2017. Leptospirosis in native mixed-breed sheep slaughtered in a semiarid region of Brazil. Ciência Rural. 47(02). http:// dx.doi.org/10.1590/0103-8478cr20160563.

7 Costa D.F., Faria P.J.A., Nogueira D.B., Tolentino L.H.O., Viana M.P., Silva J.D., Vaz A.F.M., Higino S.S.S., Azevedo S.S. \& Alves C.J. 2019. Influence of breed on the clinical and hemato-biochemical paraeters in sheep experimentally infected with Leptospira sp. Heliyon. 5(10): 02720. doi.org/10.1016/j.heliyon.2019.e02720.

8 Dorjee S., Heuer, C., Jackson, R., West, D.M. Collins-Emerson J.M., Midwinter A.C. \& Ridler A.L. 2008. Prevalence of pathogenic Leptospira spp. in sheep in a sheep-only abattoir in New Zealand. New Zealand Veterinary Journal. 56(4): 164-70. http://dx.doi.org/10.1080/00480169.2008.36829.

9 Dorneles E.M.S., Guimarães A.S., Gouveia A.M.G., Coura F.M., Carmo F.B., Pauletti R.B., Azevedo V., Lilenbaum W., Vitor R.W.A., Pinheiro R.R., Ferreira A.C.R., Dasso M.G., Lages A.P. \& Heinemann M.B. 2020. Seroprevalence of Brucella ovis-epididymitis, smooth-Brucella, leptospirosis, toxoplasmosis, and Maedi-Visna in sheep slaughtered in Minas Gerais State, Brazil. Brazilian Journal of Veterinary Research and Animal Science. 57(2): e164278. https:// doi.org/10.11606/issn.1678-4456.bjvras.2020.164278.

10 Ellis W.A. 1994. Leptospirosis as a cause of reproductive failure. Veterinary Clinics of North America, Food Animal Practice. 10: 463-478. doi: 10.1016/s0749-0720(15)30532-6.

11 Ellis W.A. 2015. Animal Leptospirosis. Current Topcis in Microbiology Immunology. 387: 99-137. doi: 10.1007/9783-662-45059-8_6.

12 Escócio C., Genovez M.E., Castro V., Piatti R.M., Gabriel F.H.L., Chiebao D.P., Azevedo S.S., Vieira S.R. \& Chiba M. 2010. Influência das condições ambientais na transmissão da leptospirose entre criações de ovinos e bovinos da região de Sorocaba, SP. Arquivo Instituto Biológico. 77(3): 371-379.

13 Fernandes C.E. 2009. Papel do ovino na cadeia epidemiológica da leptospirose pela Leptospira spp. sorovar Hardjo: fatores de risco que envolvem a infecção e transmissão entre ovinos e bovinos. 104f. São Paulo, SP. Dissertação (Mestrado em Sanidade, Segurança Alimentar e Ambiental no Agronegócio) - Programa de Pós-Graduação - Instituto Biológico (São Paulo). 
14 Fernandes J.J., Araújo Júnior J.P., Malossi C.D., Ullmann L.S., Costa D.F., Silva M.L.C.R., Alves C.J., Azevedo S.S. \& Higino S.S.S. 2020. High frequency of seropositive and carriers of Leptospira spp. in pigs in the semiarid region of northeastern Brazil. Tropical Animal Health and Production. 52: 2055-2061. https://doi.org/10.1007/s11250-02002203-y

15 Instituto Brasileiro de Geografia e Estatística (IBGE). 2017. Censo Agropecuário IBGE. Disponível em: <https:// censoagro2017.ibge.gov.br/templates/censo_agro/resultadosagro/pecuaria.html?localidade=0\&tema=75674>

16 Instituto Brasileiro de Geografia e Estatística (IBGE). 2019. Pesquisa da pecuária Municipal - PPM. Disponível em: https://sidra.ibge.gov.br/tabela/3939 [Accessed online in January 2021].

17 Lilenbaum W., Varges R., Medeiros L., Cordeiro A.G., Cavalcanti A., Souza G.N., Richtzenhain L. \& Vasconcellos S.A. 2008. Risk factors associated with leptospirosis in dairy goats under tropical conditions in Brazil. Research in Veterinary Science. 84(1): 14-21. https://doi.org/10.1016/j.rvsc.2007.03.011

18 Lilenbaum W., Varges R., Ristow P., Cortez A., Souza S.O., Richtzenhain L.J. \& Vasconcellos A.S. 2009. Identification of Leptospira spp. carriers among seroreactive goats and sheep by polymerase chain reaction. Research in Veterinary Science. 87: 16-19. doi: 10.1016/j.rvsc.2008.12.014

19 Martins G., Penna B., Hamond C., Leite R.C., Silva A., Ferreira A., Brandão F., Oliveira F. \& Lilenbaum W. 2012. Leptospirosis as the most frequent infectious disease impairing productivity in small ruminants in Rio de Janeiro, Brazil. Tropical Animal Health and Production. 44(4): 773-777. doi 10.1007/s11250-011-9964-4.

20 Martins G. \& Lilenbaum W. 2013. The panorama of animal leptospirosis in Rio de Janeiro, Brazil, regarding the seroepidemiology of the infection in tropical regions. BMC. Veterinary Research. 9: 237-243. doi: 10.1186/17466148-9-237

21 Melo L.S.S., Castro M.B., Leite R.C., Moreira É.C. \& Melo C.B. 2010. Principais aspectos da infecção por Leptospira sp. em ovinos. Ciência Rural. 40(5): 1235-1241.

22 Morais D.A., Costa D.F., Nunes B.C., Santos C.S.A.B., Alves C.J. \& Azevedo S.S. 2019. Seroepidemiological survey for leptospirosis in equines from semiarid region of Paraíba State, Northeastern Brazil. Semina: Ciências Agrárias. 40(5): 2079-2086. doi: 10.5433/1679-0359.2019v40n5p2079.

23 Nogueira D.B., Costa F.T.R., Bezerra C.S., Silva M.L.C.R., Costa D.F., Viana M.P., Silva J.D., Júnior J.P.A., Santos C.S.A.B., Alves C.J. \& Azevedo S.S. 2020. Use of serological and molecular techniques for detection of Leptospira sp. carrier sheep under semiarid conditions and the importance of genital transmission route. Acta Tropica. 207: 105-497. https://doi.org/10.1016/j.actatropica.2020.105497.

24 Nogueira D.B., Costa F.T.R, Bezerra C.S, Soares R.R., Barnabé N.N.C., Falcão B.M.R., Silva M.L.C.R., Costa D.F., Araújo Júnior J.P., Malossi C.D., Ullmannc L.S., Alves C.J. \& Azevedo S.S. 2020. A Leptospira sp. vertical transmission in ewes maintained in semiarid conditions. Animal Reproduction Science. 219: 106530. doi: 10.1016/j. anireprosci.2020.106530.

25 OIE - World Organization for Animal Health. 2014. Leptospirosis: Manual of diagnostic tests and vaccines for terrestrial animals. Paris: World Organization for Animal Health. Available at <http://www.oie.int/fileadmin/Home/eng/ Health_standards/tahm/2.01.09_LEPTO.pdf $>$.

26 Pimenta C.L.R.M., Bezerra C.S., Morais D.A., Silva M.L.C.R., Nogueira D.B., Costa D.F., Santos C.S.A.B., Higino S.S.S., Alves C.J. \& Azevedo S.S. 2019. Seroprevalence and predominant serogroups of Leptospira sp. in serological tests of ruminants in northeastern Brazil. Semina: Ciências Agrárias. 40(4): 1513-1522. doi: 10.5433/1679-0359.2019v40n4p1513.

27 Pimenta C.L.R.M., Nogueira D.B., Bezerra C.S., Morais D.A., Silva M.L.C.R., Costa D.F., Higino S.S.S., Santos C.S.A.B., Alves C.J. \& Azevedo S.S. 2020. High proportion of cattle and sheep seropositive and renal carriers of Leptospira sp. under semiarid conditions. Revista Brasileira de Ciência Veterinária. 27(1): 22-28. doi:10.4322/ rbcv.2020.005

28 Silva E.F., Brod C.S., Cerqueira G.M., Bourscheidt D., Seyffert N., Queiroz A., Santos C.S., Ko A.I. \& Dellagostin O.A. 2007. Isolation of Leptospira noguchii from sheep. Veterinary Microbiology. 121(1-2): 144-149. doi:10.1016/j. vetmic.2006.11.010.

29 Silva A.F., Farias P.J.A., Silva M.L.C.R., Araújo Júnior J.P., Malossi C.D., Ullmann L.S., Costa D.F., Higino S.S.S., Azevedo S.S. \& Alves C.J. 2018. High frequency of genital carriers of Leptospira sp. in sheep slaughtered in the semi-arid region of northeastern Brazil. Tropical Animal Health and Production. 51: 43- 47. doi: 10.1007/s11250018-1657-9. 
J.D. Silva, M.P. Viana, L.G.L.P. Calado, et al. 2021. Spatial Distribution of Serologically Reactive Sheep to Leptospira spp. in the Northeast Region of Brazil. Acta Scientiae Veterinariae. 49: 1837.

30 Soares R.R., Barnabé N.N.C., Nogueira D.B., Silva L.C., Araújo Júnior J.P., Malossi C.D., Ullmann L.S., Costa D.F., Silva M.L.C.R., Higino S.S.S., Azevedo S.S. \& Alves C.J. 2021. Serological, molecular and bacteriological approaches for detecting Leptospira sp. carrier rams maintained in semiarid conditions. Acta Tropica. 213(2021): 105759. https://doi.org/10.1016/j.actatropica.2020.105759.

31 SUDENE. 2018. Caracterização do Território Nordestino [WWW Document]. Superintendência do Desenvolvimento. do Nordeste. Disponível em: <URL http://www.sudene.gov.br/area-de-atuacao/regiaonordeste-estatisticas/nordesteem-numeros/caracterizacao-do-territorio-nordestino>. [Accessed online in December 2018].

32 Thrusfield M. \& Christley R. 2018. Veterinary Epidemiology. In: Thrusfield M. (Ed). Surveillance. 4th edn. Oxford: John Wiley \& Sons Ltd., pp.470-475. 